\title{
Assessment of Relationship Between Serum Vitamin D Levels and Metabolic Syndrome Components in Hemodialysis Patients
}

\author{
Sevil Karahan Yılmaz ${ }^{1^{*}}$ (D) Cuma Mertoğlu² (D), Aylin Ayaz ${ }^{3}$ (D)
}

\begin{abstract}
Aim: This study is aimed to evaluate the relationship between serum vitamin D levels and metabolic syndrome in hemodialysis patients.

Materials and Methods: This study was conducted with participation of 80 patients undergoing hemodialysis for more than 6 months three times a week, aged $>18$ years. Their height, dry weight, waist circumference were measured. Biochemical parameters such as serum 25-hydroxyvitamin D, lipid profile, and fasting blood glucose were analyzed. Metabolic syndrome was defined using the National Cholesterol Education Program Adult Treatment Panel III criteria. Severe vitamin D deficiency, $25(\mathrm{OH})$ vitamin $D<5 \mathrm{ng} / \mathrm{ml}$; mild vitamin D deficiency, $25(\mathrm{OH})$ vitamin D 5-15 ng/ml; vitamin D insufficiency, $25(\mathrm{OH})$ vitamin D 16-30 $\mathrm{ng} / \mathrm{ml}$, and vitamin D sufficiency, $25(\mathrm{OH})$ vitamin $\mathrm{D}>30 \mathrm{ng} / \mathrm{ml}$ were categorized. Statistical analysis of the data was performed with the use of SPSS version 21.0 .

Results: $48.4 \%$ of hemodialysis patients were identified to have metabolic syndrome. According to the serum levels of vitamin D; $35.0 \%$ of patients had severe vitamin D deficiency, $37.4 \%$ of patients had mild vitamin D deficiency, $18.8 \%$ of patients had vitamin $D$ insufficiency and $8.8 \%$ of patients had vitamin $D$ sufficiency (>30 ng/ml). Vitamin D insufficiency was significantly associated with metabolic syndrome and central obesity. Conclusions: Deficiency/insufficiency is observed in serum 25 -hydroxyvitamin D levels in hemodialysis patients. Vitamin D insufficiency is associated with metabolic syndrome.

\section{Keywords}

Hemodialysis; 25-Hydroxyvitamin D; Metabolic Syndrome

${ }^{1}$ Department of Nutrition and Dietetics, Faculty of Health Sciences, Erzincan Binali Yıldırım University, Erzincan, Turkey

${ }^{2}$ Department of Clinical Biochemistry, Faculty of Medicine, Erzincan Binali Yıldırım University, Erzincan, Turkey

${ }^{3}$ Department of Nutrition and Dietetics, Faculty of Health Sciences, Hacettepe University, Ankara, Turkey

*Corresponding author: karahany.sevil12@gmail.com
\end{abstract}

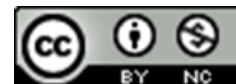

Copyright @Sevil Karahan Yılmaz, Cuma Mertoğlu, Aylin Ayaz, 2021

\section{Problem statement and analysis of the latest research}

Metabolic syndrome is defined as a set of risk factors that include insulin resistance, hypertension, high triglyceride levels, lower high-density lipoprotein cholesterol levels, and obesity (particularly central adiposity) [1]. Metabolic syndrome has risk factors for cardiovascular diseases, type 2 diabetes, and progression of hepatic and renal disorders [2].

Vitamin D is a steroid-derived hormone that is obtained from 7-dehydrocholesterol with ultraviolet light in the skin. Approximately $95 \%$ of vitamin D is synthesized in the skin under the influence of sunlight exposure [3]. Non-classical effects of vitamin D are grouped under 3 main headings: regulation of hormone secretion, immune function, and proliferation and differentiation of the cell. Active vitamin D plays an important role in maintaining normal bone mineral homeostasis and insulin secretion [4]. Vitamin D intake and serum 25-hydroxyvitamin D (25 (OH) D) levels are associated with obesity, metabolic syndrome, insulin resistance, diabetes, hypertension, cardiovascular diseases, polycystic ovary syndrome, fatty liver disease, and chronic renal failure [5].

Vitamin D deficiency is a worldwide public health problem, it increases the risk of metabolic syndrome [6]. Vitamin D deficiency plays a key role in the pathophysiology of risk factors of metabolic syndrome which affects the cardio- 
vascular system, increases insulin resistance and obesity, stimulates the renin-angiotensin-aldosterone system that causes hypertension. The discovery of vitamin D receptor expressed ubiquitously in almost all body cells such as immune, vascular and myocardial cells, pancreatic beta cells, neurons, and osteoblasts suggests involvement of vitamin D mediated effects on metabolic syndrome. Moreover, vitamin D deficiency as well as cardiovascular diseases and related risk factors, frequently co-occur. This underlines the importance of understanding the role of vitamin $\mathrm{D}$ in the context of metabolic syndrome [7]. A decrease in serum $25(\mathrm{OH})$ D vitamin level in hemodialysis is known [8] and the study that shows the relationship between vitamin D levels and metabolic syndrome is linked in a recent study only [9-11].

Objective: We aimed at the assessment of the relationship between serum vitamin D levels and metabolic syndrome components in hemodialysis patients.

\section{Materials and Methods}

This study was performed with the participation of 80 patients between September 2017-December 2017; patients have been undergoing hemodialysis in the dialysis unit of Erzincan Mengücek Gazi Education and Research Hospital for at least 6 months three times a week, and their mean age was $56.27 \pm 15.80$ years. Patients were excluded if they had acute or chronic inflammation/infection, liver failure, and cancer. All patients received Vitamin D supplements (treatment of secondary hyperparathyroidism) and phosphorus binding agent, included in the study.

A questionnaire technique was used to collect data regarding patients' general information, medical history, and physical activity. Their height, dry weight, and waist circumference were measured. Dry weight measurements were conducted at the end of hemodialysis. Their body mass index (BMI) was calculated by dividing their body weight by the square meter of height [12]. Doing or not doing regular sports/exercise, sport/exercise type, frequency, and duration were investigated for physical activity status.

The blood samples were collected in advance of the hemodialysis. Biochemical parameters as serum $25(\mathrm{OH}) \mathrm{D}$, lipid profile, fasting blood glucose (FPG), phosphorus (P), albumin, hemoglobin, parathyroid hormone (PTH), and C-reactive protein (CRP) were extracted from patient files. $25(\mathrm{OH}) \mathrm{D}$ and parathyroid hormone were analyzed in Siemens AdviaCentaur XP using a chemiluminescent immunometric assay method [13]; lipid profile, FBG, calcium (Ca), P, and albumin were analyzed in a Beckman Coulter with model number AU640 using a photometric method [14]. C-reactive protein was analyzed in Siemens Bn II using the nephelometer method [15].

The metabolic syndrome status was defined by the National Cholesterol Education Program Adult Treatment Panel III (NCEP-ATP III). According to NCEP-ATP III guidelines, metabolic syndrome was diagnosed with abdominal obesity (waist circumference $>102 \mathrm{~cm}$ for men or $>88 \mathrm{~cm}$ for women), fasting triglyceride levels $\geq 150 \mathrm{mg} / \mathrm{dl}$, reduced high-density lipoprotein cholesterol (HDL-C $<50 \mathrm{mg} / \mathrm{dl}$ for women or $<40 \mathrm{mg} / \mathrm{dl}$ for men), blood pressure of systolic $\geq 130 \mathrm{mmHg}$ and diastolic ones $\geq 85 \mathrm{mmHg}$, fasting blood glucose $\geq 100 \mathrm{mg} / \mathrm{dl}$ as three or more out of five factors to establish the diagnosis of metabolic syndrome [16].

Vitamin D status was evaluated by serum $25(\mathrm{OH})$ vitamin D levels according to the National Kidney Foundation's Kidney Disease Outcomes Quality Initiative (KDOQI). Severe vitamin D deficiency with $25(\mathrm{OH})$ vitamin $\mathrm{D}<5 \mathrm{ng} / \mathrm{ml}$; mild vitamin D deficiency with $25(\mathrm{OH})$ vitamin D 5-15 ng/ml; vitamin D insufficiency with $25(\mathrm{OH})$ vitamin D 16-30 ng/ml and vitamin D sufficiency with $25(\mathrm{OH})$ vitamin $\mathrm{D}>30 \mathrm{ng} / \mathrm{ml}$ were categorized [17].

\section{Statistical analysis}

Statistical analysis of the data was performed with the use of SPSS version 21.0 (SPSS Inc., Chicago, USA). Data are presented as mean \pm standart deviation (SD) for numeric variables and percentages for categoric variables. The "MannWhitney U Test" and "Kruskal Wallis H-Test" were used for group comparisons. The Pearson correlation analysis was used to find the relationship between two variables. To examine the relationship between vitamin $\mathrm{D}$ status and metabolic syndrome and metabolic syndrome components, multivariate logistic regression models were used. Results at $95 \%$ confidence interval, $\mathrm{p}$ values of $<0.05$ were accepted as statistically significant [18].

\section{Results}

The study included $51(63.7 \%)$ male and $29(36.3 \%)$ female hemodialysis patients whose average age was $56.27 \pm 15.80$ years. Patients were on dialysis for a median of $4.22 \pm 2.86$ years. According to NCEP-ATP III criteria, metabolic syndrome was identified in 48 (48.4\%) patients. Age, duration of dialysis, anthropometric measurements, and biochemical parameter levels of hemodialysis patients with and without metabolic syndrome are represented in Table 1. A statistically significant difference was observed in dry weight, BMI, waist circumference, triglyceride, and HDL-C levels in hemodialysis patients with and without metabolic syndrome $(\mathrm{p}<0.05)$. Dry weight, BMI, waist circumference, serum triglycerides were significantly higher and HDL-C levels were lower in patients with metabolic syndrome than in other groups.

According to physical activity status, $30.7 \%$ of patients performed regular sports/exercise, it was seen that it takes $>30$ minutes/day and 3 days/week in patients who do regular sports/exercise.

Serum $25(\mathrm{OH})$ vitamin D levels were evaluated according to National Kidney Foundation's Kidney Disease Outcomes Quality Initiative (KDOQI); 35.0\% of patients had severe vitamin D deficiency, $37.4 \%$ of patients had mild vitamin D deficiency, $18.8 \%$ of patients had vitamin D insufficiency and $8.8 \%$ of patients had vitamin D sufficiency $(>30 \mathrm{ng} / \mathrm{ml}$ ), 
Table 1. Anthropometric measurements and biochemical parameter levels of hemodialysis patient with and without metabolic syndrome.

\begin{tabular}{|c|c|c|c|}
\hline Parameters & $\begin{array}{c}\text { Metabolic syndrome }(+) \\
39(49 \%)\end{array}$ & $\begin{array}{c}\text { Metabolic syndrome(-) } \\
41(51 \%)\end{array}$ & p-value \\
\hline Age (year) & $55.92 \pm 13.99$ & $56.61 \pm 17.51$ & 0.413 \\
\hline Duration of dialysis (year) & $3.76 \pm 2.68$ & $4.67 \pm 2.98$ & 0.151 \\
\hline Dry weight $(\mathrm{kg})$ & $76.34 \pm 13.12$ & $63.30 \pm 12.82$ & $<0.001 *$ \\
\hline \multicolumn{4}{|l|}{ Body mass index $\left(\mathrm{kg} / \mathrm{m}^{2}\right)$} \\
\hline Male & $26.32 \pm 3.31$ & $23.76 \pm 3.81$ & $0.009 *$ \\
\hline Female & $30.38 \pm 5.70$ & $21.77 \pm 3.68$ & $0.010^{*}$ \\
\hline \multicolumn{4}{|l|}{ Waist circumference $(\mathrm{cm})$} \\
\hline Male & $100.35 \pm 8.64$ & $91.90 \pm 9.78$ & $0.001 *$ \\
\hline Female & $100.89 \pm 12.18$ & $81.50 \pm 13.04$ & $0.002 *$ \\
\hline Systolic blood pressure $(\mathrm{mmHg})$ & $127.94 \pm 27.35$ & $122.68 \pm 23.56$ & 0.300 \\
\hline Diastolic blood pressure ( $\mathrm{mmHg}$ ) & $73.74 \pm 20.03$ & $69.51 \pm 10.23$ & 0.230 \\
\hline Fasting plasma glucose $(\mathrm{mg} / \mathrm{dL})$ & $133.73 \pm 58.24$ & $115.14 \pm 85.43$ & 0.300 \\
\hline Cholesterol (mg/dL) & $183.00 \pm 40.56$ & $166.36 \pm 43.10$ & 0.052 \\
\hline Triglycerides $(\mathrm{mg} / \mathrm{dL})$ & $231.67 \pm 103.06$ & $159.97 \pm 120.50$ & $<0.001 *$ \\
\hline Low density lipoprotein cholesterol (mg/dL) & $106.14 \pm 35.61$ & $93.73 \pm 32.36$ & 0.103 \\
\hline High density lipoprotein cholesterol $(\mathrm{mg} / \mathrm{dL})$ & $33.78 \pm 6.76$ & $38.67 \pm 9.76$ & $0.042 *$ \\
\hline Uric acid $(\mathrm{mg} / \mathrm{dL})$ & $6.44 \pm 1.34$ & $6.07 \pm 1.89$ & 0.310 \\
\hline Albumin $(\mathrm{mg} / \mathrm{dL})$ & $3.95 \pm 1.02$ & $3.95 \pm 0.85$ & 0.999 \\
\hline Phosphoros (mmol/L) & $4.91 \pm 1.15$ & $5.19 \pm 1.42$ & 0.334 \\
\hline $25(\mathrm{OH}) \mathrm{D}(\mathrm{nmol} / \mathrm{L})$ & $12.30 \pm 1.49$ & $11.21 \pm 1.41$ & 0.601 \\
\hline Hemoglobin $(\mathrm{g} / \mathrm{L})$ & $11.86 \pm 1.27$ & $11.77 \pm 2.01$ & 0.487 \\
\hline Parathyroid hormone $(\mathrm{pg} / \mathrm{mL})$ & $579.95 \pm 82.54$ & $798.44 \pm 92.07$ & 0.061 \\
\hline C-reactive protein $(\mathrm{mg} / \mathrm{dL})$ & $11.75 \pm 2.85$ & $10.40 \pm 1.92$ & 0.703 \\
\hline
\end{tabular}

Notes: ${ }^{*} \mathrm{p}<0.05$, Mann-Whitney U Test.

serum $25(\mathrm{OH}) \mathrm{D}$ as a deficiency (mean $11.74 \pm 81.42 \mathrm{nmol}$ ) was determined. Anthropometric measurements and biochemical parameter levels of hemodialysis patients according to serum $25(\mathrm{OH}) \mathrm{D}$ level are represented in Table 2. There was no statistically significant difference in age, dialysis duration, BMI, waist circumference, systolic blood pressure, diastolic blood pressure, fasting blood glucose, cholesterol, triglycerides, HDL-C, low-density lipoprotein cholesterol (LDL-C), uric acid, PTH, and CRP levels ( $p>0.05$ ); only there was a significant difference in waist circumference $(p<0.05)$ in patients whose Vitamin D status was evaluated according to severe deficiency, mild deficiency, insufficiency and sufficiency. There was no significant relationship between serum $25(\mathrm{OH}) \mathrm{D}$ level and waist circumference, systolic blood pressure, diastolic blood pressure, fasting blood sugar, triglycerides, and HDL-C.

As shown in Table 3, vitamin D insufficiency was significantly associated with metabolic syndrome and central obesity. No associations between severe deficiency, mild deficiency, and insufficiency and raised triglycerides, reduced HDL-C, raised blood pressure, or raised fasting plasma glucose were identified.

\section{Discussion}

In the study which planned to evaluate the relationship between serum $25(\mathrm{OH}) \mathrm{D}$ and metabolic syndrome components in hemodialysis patients, metabolic syndrome was identified in $48(48.4 \%)$ patients. In a study of hemodialysis patients, metabolic syndrome was identified in 61 (56.5\%) of patients according to NCEP-ATP III criteria [19]. In another study, according to the International Diabetes Federation (IDF) criteria for metabolic syndrome, 241 (38.2\%) hemodialysis patients had metabolic syndrome [20]. There were 115 hemodialysis patients evaluated by NCEP-ATP III and the International Diabetes Federation (IDF) criteria; metabolic syndrome was identified according to NCEP-ATP III $41.7 \%$ and IDF $42.6 \%$ [21]. Metabolic syndrome was $50.0 \%$ in 100 hemodialysis patients according to NCEP-ATP III criteria [22]. Vogt and others identified metabolic syndrome in $98(74.5 \%)$ patients according to IDF criteria [23]. In another study, according to NCEP-ATP III 80 (24.7\%) hemodialysis patients had metabolic syndrome [24]. Ahmadi and others performed a study with the participation of 145 hemodialysis patients, and provided that metabolic syndrome was identified according to IDF criteria $53.1 \%$ [9]. In 143 hemodialysis patients, metabolic syndrome was identified according to IDF criteria $45.5 \%$ [10]. In another study, according to IDF cri- 
Table 2. Anthropometric measurements and biochemical parameter levels of hemodialysis patients according to serum 25 $(\mathrm{OH}) \mathrm{D}$ level.

\begin{tabular}{|c|c|c|c|c|c|}
\hline \multirow[b]{2}{*}{ Parameters } & \multicolumn{4}{|c|}{ Vitamin D status } & \multirow[b]{2}{*}{$\mathrm{p}$-value } \\
\hline & $\begin{array}{c}\text { Severe deficiency } \\
28(35 \%)\end{array}$ & $\begin{array}{c}\text { Deficiency } \\
30(38 \%)\end{array}$ & $\begin{array}{c}\text { Insufficiency } \\
15(19 \%)\end{array}$ & $\begin{array}{c}\text { Sufficiency } \\
7(8 \%)\end{array}$ & \\
\hline Age (year) & $54.64 \pm 15.61$ & $56.43 \pm 15.83$ & $58.13 \pm 17.10$ & $58.14 \pm 16.44$ & 0.965 \\
\hline Duration dialysis (year) & $4.67 \pm 2.65$ & $4.41 \pm 2.60$ & $3.38 \pm 0.92$ & $3.42 \pm 1.18$ & 0.107 \\
\hline Body mass index $\left(\mathrm{kg} / \mathrm{m}^{2}\right)$ & $24.87 \pm 3.87$ & $25.12 \pm 6.15$ & $24.56 \pm 5.82$ & $24.16 \pm 6.78$ & 0.809 \\
\hline Waist circumference $(\mathrm{cm})$ & $94.75 \pm 10.43$ & $92.43 \pm 15.52$ & $96.34 \pm 18.42$ & $93.36 \pm 14.70$ & $0.006^{*}$ \\
\hline Systolic blood pressure $(\mathrm{mmHg})$ & $124.35 \pm 31.10$ & $117.56 \pm 18.78$ & $124.46 \pm 24.56$ & $116.62 \pm 25.13$ & 0.844 \\
\hline Diastolic blood pressure $(\mathrm{mmHg})$ & $69.34 \pm 9.91$ & $71.23 \pm 9.54$ & $73.01 \pm 14.13$ & $70.12 \pm 10.89$ & 0.847 \\
\hline Fasting plasma glucose $(\mathrm{mg} / \mathrm{dL})$ & $117.89 \pm 57.96$ & $104.09 \pm 36.12$ & $120.55 \pm 64.56$ & $117.12 \pm 59.73$ & 0.920 \\
\hline Cholesterol (mg/dL) & $159.86 \pm 32.67$ & $175.18 \pm 44.12$ & $182.45 \pm 58.80$ & $183.89 \pm 74.32$ & 0.154 \\
\hline Triglycerides $(\mathrm{mg} / \mathrm{dL})$ & $159.30 \pm 81.33$ & $154.29 \pm 58.54$ & $194.77 \pm 111.34$ & $188.09 \pm 113.93$ & 0.425 \\
\hline $\begin{array}{l}\text { High density lipoprotein choles- } \\
\text { terol }(\mathrm{mg} / \mathrm{dL})\end{array}$ & $37.24 \pm 9.55$ & $36.18 \pm 10.29$ & $4 \pm 9.2$ & \pm 14.10 & 0.444 \\
\hline $\begin{array}{l}\text { Low density lipoprotein choles- } \\
\text { terol }(\mathrm{mg} / \mathrm{dL})\end{array}$ & $95.98 \pm 24.06$ & $109.78 \pm 34.13$ & $107.67 \pm 69.18$ & $102.68 \pm 36.64$ & 0.225 \\
\hline Uric acid $(\mathrm{mg} / \mathrm{dL})$ & $5.81 \pm 1.27$ & $6.58 \pm 2.49$ & $6.25 \pm 1.35$ & $6.20 \pm 0.66$ & 0.734 \\
\hline Parathyroid hormone $(\mathrm{pg} / \mathrm{mL})$ & $843.70 \pm 484.56$ & $727.58 \pm 614.66$ & $707.98 \pm 707.89$ & $157.64 \pm 71.25$ & 0.299 \\
\hline C-reactive protein $(\mathrm{mg} / \mathrm{dL})$ & $17.96 \pm 14.70$ & $23.11 \pm 18.87$ & $12.58 \pm 10.29$ & $15.24 \pm 12.72$ & 0.582 \\
\hline
\end{tabular}

Notes: $\mathrm{p}>0.05$, Kruskal Wallis Test.

Table 3. Association of vitamin D status with the metabolic syndrome and components of the metabolic syndrome among the hemodialysis patients.

\begin{tabular}{|c|c|c|c|c|c|c|}
\hline & \multicolumn{4}{|c|}{ Vitamin D status } & \multirow{2}{*}{\multicolumn{2}{|c|}{ Insufficiency }} \\
\hline & \multicolumn{2}{|c|}{ Severe deficiency } & \multicolumn{2}{|c|}{ Mild deficiency } & & \\
\hline & OR $(95 \% \mathrm{CI})$ & p-value & OR $(95 \% \mathrm{CI})$ & p-value & OR $(95 \% \mathrm{CI})$ & p-value \\
\hline & \multicolumn{6}{|c|}{ Adjusted for age and sex } \\
\hline Metabolic syndrome & $2.70(1.02-9.36)$ & 0.300 & $2.41(0.5-9.96)$ & 0.921 & $3.34(1.20-8.60)$ & $0.030^{*}$ \\
\hline Central obesity & $0.65(0.39-1.28)$ & 0.816 & $0.72(0.50-1.49)$ & 0.218 & $0.98(0.65-1.78)$ & $0.002 *$ \\
\hline Raised triglycerides & $1.54(1.36-1.80)$ & 0.148 & $1.45(0.95-2.21)$ & 0.090 & $1.53(1.15-2.48)$ & 0.876 \\
\hline $\begin{array}{l}\text { Reduced high-density lipoprotein } \\
\text { cholesterol }\end{array}$ & $0.85(0.63-1.80)$ & 0.645 & $1.05(0.84-2.12)$ & 0.432 & $0.93(0.61-1.98)$ & 0.149 \\
\hline Raised blood pressure & $1.57(0.20-1.71)$ & 0.078 & $0.95(0.23-2.38)$ & 0.110 & $1.51(1.30-1.88)$ & 0.315 \\
\hline Raised fasting plasma glucose & $1.13(0.56-2.05)$ & 0.322 & $1.22(0.76-2.49)$ & 0.087 & $0.92(0.58-2.23)$ & 0.675 \\
\hline
\end{tabular}

Notes: In all models, vitamin D sufficiency was designated as the reference category (odds ratio $=1.00$ ).

teria, $90(25.3 \%)$ hemodialysis patients had metabolic syndrome [11]. In studies, the prevalence of metabolic syndrome in hemodialysis patients varies according to the diagnostic criteria for metabolic syndrome and the number of patients [911, 19-23]. It appears, that the prevalence of metabolic syndrome among patients on hemodialysis was nearly half in different studies $[9,10,21,22]$ and metabolic syndrome identified in this study $(48.4 \%)$, were similar.

A recent meta-analysis showed that different components in the metabolic syndrome negatively affect the kidney in different proportions in terms of proteinuria, and it showed their effect in descending order to be hypertension, hypertriglyceridemia, low HDL-C, abdominal obesity, and impaired glucose intolerance [25]. Also supporting studies made in $[9,10,21,24,26]$, dry weight, BMI, waist circumference, serum triglycerides were significantly higher and HDL-C levels were lower in patients with metabolic syndrome than other groups. As in this study, BMI is also high in patients with metabolic syndrome $(p<0.05)$, is an independent predictor of metabolic syndrome in hemodialysis patients without diabetes and dyslipidemia [9, 15, 22, 24, 27]. These discrepancies in the results of different studies could be attributed to the different populations and healthcare settings between these studies and the current study.

Vitamin D deficiency is a worldwide public health problem seen in hemodialysis patients. In this study, according to the serum levels of vitamin D $35.0 \%$ of patients had severe vitamin D deficiency, $37.4 \%$ of patients had mild vitamin D 
deficiency, $18.8 \%$ of patients had vitamin D insufficiency and $8.8 \%$ of patients had vitamin D sufficiency $(>30 \mathrm{ng} / \mathrm{ml})$, serum $25(\mathrm{OH}) \mathrm{D}$ as a deficiency (mean $11.74 \pm 81.42 \mathrm{nmol}$ ) was determined and vitamin $\mathrm{D}$ deficiency/insufficiency is found in near almost all of the patients $(91.2 \%)$. To determine the vitamin D deficiency in hemodialysis patients in another study performed with the participation of 187 patients, mean serum $25(\mathrm{OH})$ D level was $11.7 \pm 7.5 \mathrm{ng} / \mathrm{ml}$; just sufficiency in $4 \%$, deficiency in $73 \%$, insufficiency in $23 \%$ of patients was found [8]. In a study with the participation of 47 patients to determine serum vitamin D level in hemodialysis patients, deficiency in $72.4 \%$ of patients, insufficiency in $23.4 \%$ of patients, and sufficiency in $4.3 \%$ of patients were identified [28]. In a study with the participation of 145 patients, mean serum vitamin D levels of $24.7 \pm 16.1 \mathrm{ng} / \mathrm{ml}$, severe deficiency in $3.4 \%$ of patients, deficiency in $31 \%$ of patients, insufficiency in $36.6 \%$ of patients, and sufficiency in $29 \%$ of patients were found [9]. Pinghua and others found that according to the levels of $25(\mathrm{OH}) \mathrm{D} 3$, patients were included into sufficient group $33(23.1 \%)$, insufficient group 69 $(48.2 \%)$, and deficient group $41(28.7 \%)$ [10]. Kara and others showed that patients with serum $25(\mathrm{OH})$ D levels $<20 \mathrm{ng} / \mathrm{ml}$, were classified as those having a vitamin D deficiency 83 $(64.3 \%)$ and those with serum $25(\mathrm{OH})$ D levels $\geq 20 \mathrm{ng} / \mathrm{ml}$ were classified as having normal vitamin D levels 46 (35.7\%). The mean serum $25(\mathrm{OH}) \mathrm{D}$ levels were $11.13 \pm 3.60 \mathrm{ng} / \mathrm{ml}$ in the deficient group and $27.04 \pm 7.20 \mathrm{ng} / \mathrm{ml}$ in the normal group [29]. The results of this study are in line with the results of studies on this issue [8].

Although it is known that vitamin D deficiency increases the risk of metabolic syndrome [6], low serum vitamin D levels in were found to be associated with the metabolic syndrome in studies $[9,10]$, but another study concluded that there is a lack of association between serum $25(\mathrm{OH})$ vitamin D concentrations and metabolic syndrome in hemodialysis patients [11]. There was a relationship between vitamin D deficiency and components of metabolic syndrome as central obesity and fasting blood glucose [9]. Low $25(\mathrm{OH})$ D3 level negatively correlated with abnormal metabolic factors central obesity, raised TG, reduced HDL-C, raised SBP, and raised FBG [10]. In another study, both vitamin D mild deficiency and insufficiency were found to be significantly associated with central obesity [11]. In this study, vitamin D levels in hemodialysis patients were deficiency/insufficiency and vitamin D insufficiency was significantly associated with metabolic syndrome and central obesity.

Vitamin D deficiency is lower in obese individuals due to insufficient intake of vitamin D, dressing more closed than normal-weight individuals, and due to less outdoor physical activity, and because of their high fat mass, vitamin D storage rate and consequently decrease in bioavailability, obese individuals are in subcutaneous adipose tissue. The levels of 25-hydroxylase and 1-alpha hydroxylase, which are the enzymes that activate vitamin $\mathrm{D}$, are considered to be decreased. In addition, vitamin $\mathrm{D}$ deficiency in obese individuals can support lipogenesis and weight gain [30].

\section{Conclusions}

An increase was seen in BMI, waist circumference, triglyceride, and HDL levels which components of the metabolic syndrome in hemodialysis patients. Deficiency/insufficiency of serum vitamin D levels was in hemodialysis patients, and vitamin D insufficiency was significantly associated with metabolic syndrome and central obesity. Appropriate nutrition programs to patients should be prepared for hemodialysis patients to achieve their ideal weight and to control which is a component of metabolic syndrome, blood sugar, and triglyceride levels and follow-up should be done regularly. The physician gave vitamin D supplements to patients who diagnosed deficiency/insufficiency of vitamin D in hemodialysis patients, overcoming deficiency/insufficiency of vitamin D. Sun exposure is the most important determinant of vitamin D in hemodialysis patients. Seasonal variation is an important parameter affecting sun exposure. Peak vitamin D levels are in autumn or the end of summer and the lowest levels are in spring or the end of winter. Sun exposure level is also important. Sun exposure time $>6$ hours/week or active physical activity $>30 \mathrm{~min} /$ day and 3 days/week may have a positive impact on both their vitamin D levels and the metabolic syndrome.

\section{Prospects of Further Researches}

The limitations of this study, small sample and to conduct this study in a single-center, unfavorable evaluation of sun exposure conditions are the shortcomings of this investigation. Long-term randomized controlled trials are needed to determine the relationship between metabolic syndrome components and vitamin D levels.

\section{Ethical Statement}

All procedures were performed in studies involving human participants, were conducted in accordance with the ethical standards of the Institutional Research Committee (Erzincan University Ethics Committee approved this study on the 14 September, 2015, the number of 09/13) and with the 1964 Helsinki Declaration and its later amendments or comparable ethical standards.

\section{Informed Consent}

Informed consent form was obtained from the subjects before the study.

\section{Conflict of Interest}

The authors declare no potential conflicts of interest with respect to the research, authorship, and/or publication of this article. 


\section{Financial Disclosure}

The authors received no financial support for the research, authorship, and/or publication of this article.

\section{Acknowledgements}

Thanks to all the families that participated in this research.

\section{References}

[1] Delautre A, Chantrel F, Dimitrov Y, Klein A, Imhoff O, Muller C, et al. Metabolic syndrome in haemodialysis patients: prevalence, determinants and association to cardiovascular outcomes. BMC Nephrology [Internet]. 2020 Aug 13;21(1). Available from: https://doi.org/10.1186/s12882-020-02004-3

[2] Duong TV, Wong T-C, Chen H-H, Chen T-W, Chen T$\mathrm{H}$, Hsu Y-H, et al. The cut-off values of dietary energy intake for determining metabolic syndrome in hemodialysis patients: A clinical cross-sectional study. PLOS ONE [Internet]. 2018 Mar 14;13(3):e0193742. Available from: https://doi.org/10.1371/journal.pone.0193742

[3] Kleine C-E, Obi Y, Streja E, Hsiung J-T, Park $\mathrm{C}$, Holick MF, et al. Seasonal variation of serum 25-hydroxyvitamin $\mathrm{D}$ and parameters of bone and mineral disorder in dialysis patients. Bone [Internet]. 2019 Jul;124:158-165. Available from: https://doi.org/10.1016/j.bone.2019.03.003

[4] Molina P, Carrero JJ, Bover J, Chauveau P, Mazzaferro S, Torres PU, et al. Vitamin D, a modulator of musculoskeletal health in chronic kidney disease. Journal of Cachexia, Sarcopenia and Muscle [Internet]. 2017 Jul 3;8(5):686-701. Available from: https://doi.org/10.1002/jcsm.12218

[5] Milajerdi A, Ostadmohammadi V, Amirjani S, Kolahdooz F, Asemi Z. The effects of vitamin D treatment on glycemic control, serum lipid profiles, and C-reactive protein in patients with chronic kidney disease: a systematic review and meta-analysis of randomized controlled trials. International Urology and Nephrology [Internet]. 2019 Jul 23;51(9):1567-1580. Available from: https://doi.org/10.1007/s11255-019-02236-9

[6] Franca Gois P, Wolley M, Ranganathan D, Seguro A. Vitamin D Deficiency in Chronic Kidney Disease: Recent Evidence and Controversies. International Journal of Environmental Research and Public Health [Internet]. 2018 Aug 17;15(8):1773. Available from: https://doi.org/10.3390/ijerph15081773

[7] Prasad P, Kochhar A. Interplay of vitamin D and metabolic syndrome: A review. Diabetes \&
Metabolic Syndrome: Clinical Research \& Reviews [Internet]. 2016 Apr;10(2):105-112. Available from: https://doi.org/10.1016/j.dsx.2015.02.014

[8] Marinelli A, Pistolesi V, Rossi V, Battista M, Buono A, Grutto Della F, et al. Severe 25-OH vitamin D deficiency in patients on chronic hemodialysis. G Ital Nefrol. 2014;31(5):gin/31.5.7. Available from: https://pubmed.ncbi.nlm.nih.gov/25315725/

[9] Ahmadi F, Damghani S, Lessan-Pezeshki M, Razeghi E, Maziar S, Mahdavi-Mazdeh M. Association of low vitamin D levels with metabolic syndrome in hemodialysis patients. Hemodialysis International [Internet]. 2015 May 20;20(2):261-269. Available from: https://doi.org/10.1111/hdi.12316

[10] Meng P, Wei F, Wang Z, Lu Z, Jia L, Bi X. Relationship between low vitamin $\mathrm{D}$ level and metabolic syndrome in maintenance hemodialysis patients. Chinese Journal of Nephrology. 2018;34(1):10-16. Available from: http://www.cjn.org.cn/EN/abstract/abstract2932.shtml

[11] Salama AS, Helmy AK, Tawfik HM, Hasan RM. Association between vitamin $\mathrm{D}$ level and metabolic syndrome in hemodialysis patients. MJMR. 2017;82(1):154-154.

[12] Pekcan G. Hastanın beslenme durumunun saptanması. In: Baysal A, editör. Diyet El Kitabı. Ankara: Hatipoğlu Yayınevi; 2018. p. 67-142.

[13] Amal L, Bergmann P. Evaluation of a chemiluminescence immunoassay for the determination of intact parathyroid hormone using the ADVIA Centaur. Clin Lab. 2004;50(11-12):695-702. Available from: https://pubmed.ncbi.nlm.nih.gov/15575312/

[14] Nauck M, Warnick GR, Rifai N. Methods for Measurement of LDL-Cholesterol: A Critical Assessment of Direct Measurement by Homogeneous Assays versus Calculation. Clinical Chemistry [Internet]. 2002 Feb 1;48(2):236-254. Available from: https://doi.org/10.1093/clinchem/48.2.236

[15] Roberts WL, Sedrick R, Moulton L, Spencer A, Rifai N. Evaluation of Four Automated High-Sensitivity C-Reactive Protein Methods: Implications for Clinical and Epidemiological Applications. Clinical Chemistry [Internet]. 2000 Apr 1;46(4):461-468. Available from: https://doi.org/10.1093/clinchem/46.4.461

[16] Third Report of the National Cholesterol Education Program (NCEP) Expert Panel on Detection, Evaluation, and Treatment of High Blood Cholesterol in Adults (Adult Treatment Panel III) Final Report. Circulation [Internet]. 2002 Dec 17;106(25):3143-3143. Available from: https://doi.org/10.1161/circ.106.25.3143 
[17] National Kidney Foundation. K/DOQI clinical practice guidelines for bone metabolism and disease in chronic kidney disease. Am J Kidney Dis. 2003;42(4 Suppl 3):1-201. Available from: https://pubmed.ncbi.nlm.nih.gov/14520607/

[18] Alpar R. Spor, sağlık ve eğitim bilimlerinden örneklerle uygulamalı istatistik ve geçerlik-güvenirlik. 4. Baskı. Ankara: Nobel Yayınevi; 2016.

[19] Alshelleh S, AlAwwa I, Oweis A, AlRyalat SA, AlEssa M, Saeed I, et al. Prevalence of metabolic syndrome in dialysis and transplant patients. Diabetes, Metabolic Syndrome and Obesity: Targets and Therapy [Internet]. 2019 Apr;12:575-579. Available from: https://doi.org/10.2147/DMSO.S200362

[20] Alswat KA, Althobaiti A, Alsaadi K, Alkhaldi AS, Alharthi MM, Abuharba WA, et al. Prevalence of Metabolic Syndrome Among the End-Stage Renal Disease Patients on Hemodialysis. Journal of Clinical Medicine Research [Internet]. 2017;9(8):687-694. Available from: https://doi.org/10.14740/jocmr3064w

[21] Kubrusly M, Oliveira CMC de, Simões PSF, Lima R de O, Galdino PNR, Sousa P de AF, et al. Prevalence of Metabolic Syndrome according to NCEP-ATP III and IDF criteria in Patients on Hemodialysis. Jornal Brasileiro de Nefrologia [Internet]. 2015;37(1). Available from: https://doi.org/10.5935/0101-2800.20150011

[22] El Ati Z, Machfar H, Boussafa H, Ati N, Omrane Sioud O, Zantour B, et al. Metabolic syndrome, malnutrition, and its associations with cardiovascular and all-cause mortality in hemodialysis patients: Followup for three years. Saudi Journal of Kidney Diseases and Transplantation [Internet]. 2020;31(1):129. Available from: https://doi.org/10.4103/1319-2442.279932

[23] Vogt BP, Ponce D, Caramori JCT. Anthropometric Indicators Predict Metabolic Syndrome Diagnosis in Maintenance Hemodialysis Patients. Nutrition in Clinical Practice [Internet]. 2015 Sep 4;31(3):368-374. Available from: https://doi.org/10.1177/0884533615601849

[24] Guo Y, Xiong Z, Su M, Huang L, Liao J, Xiao H, et al. Positive association of SCD1 genetic variation and metabolic syndrome in dialysis patients in China. Personalized Medicine [Internet]. 2020 Mar;17(2):111-119. Available from: https://doi.org/10.2217/pme-2019-0020
[25] Thomas G, Sehgal AR, Kashyap SR, Srinivas TR, Kirwan JP, Navaneethan SD. Metabolic Syndrome and Kidney Disease: A Systematic Review and Meta-analysis. Clinical Journal of the American Society of Nephrology [Internet]. 2011 Aug 18;6(10):2364-2373. Available from: https://doi.org/10.2215/CJN.02180311

[26] Chang Y-M, Shiao C-C, Huang Y-T, Chen I-L, Yang C-L, et al. Impact of metabolic syndrome and its components on heart rate variability during hemodialysis: a cross-sectional study. Cardiovascular Diabetology [Internet]. 2016 Jan 27;15(1). Available from: https://doi.org/10.1186/s12933-016-0328-2

[27] Dimitrijevic Z, Jovanovic A, Cvetkovic M, Vrecic T, Kostic E, Mitic B. Associations of Cardiovascular and AllCause Mortality with Metabolic Syndrome in Hemodialysis Patients: A Prospective Single-Center Study. Medicina [Internet]. 2019 Oct 16;55(10):694. Available from: https://doi.org/10.3390/medicina55100694

[28] Lee YJ, Oh IH, Baek HJ, Lee CH, Lee SS. Effects of sun exposure and dietary vitamin $D$ intake on serum 25-hydroxyvitamin D status in hemodialysis patients. Nutrition Research and Practice [Internet]. 2015;9(2):158. Available from: https://doi.org/10.4162/nrp.2015.9.2.158

[29] Kara AV, Soylu YE. The relationship between vitamin D and inflammatory markers in maintenance hemodialysis patients. International Urology and Nephrology [Internet]. 2019 Aug 5;51(9):1659-1665. Available from: https://doi.org/10.1007/s11255-019-02250-x

[30] Migliaccio S, Di Nisio A, Mele C, Scappaticcio L, Savastano S, et al. Obesity and hypovitaminosis D: causality or casualty? International Journal of Obesity Supplements [Internet]. 2019 Apr;9(1):20-31. Available from: https://doi.org/10.1038/s41367-019-0010-8

Received: 2020-10-23

Revised: $2020-12-03$

Accepted: 2020-12-15 